\title{
Closing the Gap and Indigenous housing
}

\section{More comprehensive investment is needed to abate the extreme disadvantage experienced in some Aboriginal communities}

oor housing, inadequate hygiene practices and household overcrowding directly or indirectly underlie many of the health and social problems present in most remote Aboriginal communities in the Northern Territory.

Improving housing and hygiene and reducing household overcrowding are fundamental developmental steps to reduce the extreme disadvantage experienced in remote Aboriginal communities. ${ }^{1-2}$ These improvements are not only essential to improve health outcomes, but are also a prerequisite for the success of current government efforts to increase participation in the workforce, improve school attendance rates and develop safe communities. ${ }^{3}$

In this article, I discuss Australian and NT Government policies and programs aimed at Closing the Gap on Indigenous disadvantage in remote Aboriginal community contexts.

\section{Current initiatives}

The Australian Government's agenda to close the gap on Indigenous disadvantage is driven by three imperatives:

- to overcome decades of underinvestment in services and infrastructure;

- to encourage and support personal responsibility as the foundation for healthy, functional families and communities; and

- to build new understanding and respect between Indigenous and non-Indigenous Australians. ${ }^{4}$

The policy approach includes the identification of seven key "building blocks" to address specific areas of Indigenous disadvantage - early childhood, schooling, healthy homes, safe communities, economic participation, and governance and leadership.

Through the National Partnership Agreement on Remote Indigenous Housing, the Australian Government is investing $\$ 5.5$ billion nationally over 10 years "to tackle the housing backlog across remote Australia and to help reduce overcrowding in Indigenous communities" . ${ }^{4}$ Under the Strategic Indigenous Housing and Infrastructure Program (SIHIP), at a cost of $\$ 672$ million, the Australian and NT governments will build 750 new homes, rebuild 230 existing houses and refurbish 2500 houses across 73 remote Indigenous communities and several community living areas (town camps) in the NT by $2013 .^{5}$ A new system to manage public housing in remote communities has been introduced. This system includes introduction of tenancy agreements, payment of fair rent, an improved process for repairs and maintenance to homes, and improved tenant support services. ${ }^{6}$

\section{Influences on the household mix}

Despite these initiatives, it appears that governments still do not recognise the complex social and cultural issues that underlie housing, health and social issues present in many remote Aboriginal communities in the NT. ${ }^{7,8}$ NonIndigenous health workers in remote communities learn about some local practices because they need to be accommodated in the workplace - for example, avoidance relationships that exist between individuals (in some communities, between brother and sister) and protocols concerning "men's business" or "women's business". However, little or nothing is known about how cultural observances shape householders' day-to-day living practices, especially hygiene behaviour, and how housing infrastructure is perceived and used.

Household overcrowding is more complex than a couple and their children living in a house too small for their needs. ${ }^{9}$ Rather, household membership comprises extended family members, and frequently includes one or more individuals with special needs (eg, frail older people, or people with psychiatric disorders and/or in poor health from chronic diseases). Households experience higher levels of stress when the behaviour of one or more family members is affected by misuse of alcohol, drugs, kava or petrol, or if problem gambling is an issue. More stress is added when a family member is in the court system, imprisoned or in juvenile detention. This household mix presents challenges for those caring for children, and those who wish to maintain good personal and domestic hygiene, and keep their house in a good condition.

\section{No quick fix}

Without more extensive initiatives, providing a limited number of new, renovated and refurbished houses (compared with the size of the need) will not directly increase employment, improve school attendance, or make remote communities safer.

That housing is seen as a quick fix is reflected in three case studies in the Closing the Gap - Prime Minister's report 2011. ${ }^{4}$ In these case studies, it is inferred that new housing will enable one tenant to become employed; children will now attend school; and one tenant will now teach his children to keep the house clean. Research has shown that providing infrastructure alone will not resolve the social and cultural factors that shape people's attitudes and behaviours. $^{10,11}$ enzies School of Health Research, Charles Darwin University, Darwin, NT.

Elizabeth.McDonald@ menzies.edu.au

doi: 10.5694/mjal1.10376

Reflection p 726

\section{A need for support}

In late January 2011, the Australian Government reported the completion of 179 new houses and 1036 rebuilds or refurbishments in the NT. ${ }^{5}$ These additional and improved houses meet an urgent need, but it is of concern that very 
little has occurred to provide tenant support programs, such as life skills or homemaker programs, and improved repairs and maintenance services. Without these programs, any health or social gains as a result of the additional or improved housing are likely to be minimal. ${ }^{10,12}$

Communities' desire for such support is evident from a perusal of Local Implementation Plans (plans developed through close consultation between governments and local reference groups that set out the priorities for each community as part of the Working Future program in the NT) ${ }^{13}$ Of the 11 NT Plans publicly available at the time of writing, eight indicate a desire for programs (eg, life skills and/or improved repairs and maintenance programs) to achieve healthy housing.

\section{Addressing key factors}

The size of the housing backlog, the poor state of many existing houses and the level of overcrowding suggest that four key factors need to be addressed in unison to achieve healthy housing in the remote Aboriginal community context:

- all existing housing stock be maintained in good condition;

- overcrowding be incrementally reduced by continuing to provide additional housing;

- appropriate, acceptable programs that are intensive and ongoing be provided to help improve standards of personal, domestic and environmental hygiene; and

- multifactorial tenant support programs be set up to deal with underlying social and other issues. ${ }^{10,14}$

Regrettably, there is little or no good-quality evidence available to know what interventions might work in this context. In the past, health promotion and life skill programs have either not been evaluated, or the evaluations have lacked rigour; as a result, the strength of any available evidence is poor. ${ }^{15}$ Past housing construction and repairs and maintenance programs in remote Aboriginal communities are contentious and generally viewed as failed or failing. ${ }^{16,17}$ Political imperatives driving the Indigenous health and housing agenda have resulted in a failure to accumulate a knowledge base in these areas. Reviews are conducted to monitor the management of $\mathrm{SIHIP}_{1}^{16}$ but no mechanisms appear to be in place to prevent the unintended negative consequences of past housing policies being repeated.

There is a danger that if Closing the Gap programs do not demonstrate progress (especially as this concerns housing), the commitment by governments to deal with the wider social determinants of health will lessen. Instead, narrow lifestyle interventions focusing on personal responsibility and individual behaviours will be introduced. There are examples of this happening already (introduction of tenancy agreements as the primary means to modify tenants' behaviour; ${ }^{18}$ income management and the introduction of the BasicsCard; ${ }^{19}$ withholding the welfare payments to parents whose children do not attend school; ${ }^{20}$ and fining parents for children's non-attendance at school ${ }^{21}$ ). These measures all reflect a simplified approach to deal with complex problems, and in most cases are not likely to be successful. $^{22,23}$

\section{More must be done}

A recent strategic review of health inequalities in England recommended that to reduce the steepness of the social gradient in health, actions need to be universal, "but with a scale and intensity that is proportionate to the level of disadvantage" ${ }^{3}$. The current approach to housing in remote communities falls short both in scale and intensity when compared with the extreme disadvantage experienced in these communities.

To achieve major improvements in overall living conditions, and other Closing the Gap programs (especially education, employment and making communities safer), greater investment in a range of social and public health programs needs to accompany the current investment in infrastructure.

Acknowledgements: I am supported by a National Health and Medical Research Council Training Fellowship for Aboriginal and Torres Strait Islander research (grant no. 490335)

Competing interests: No relevant disclosures.

Provenance: Not commissioned; externally peer reviewed.

\section{References}

1 McDonald E, Bailie R, Grace J, et al. A case study of physical and social barriers to hygiene and child growth in remote Australian Aboriginal communities. BMC Public Health 2009; 9: 346.

2 Biddle N, Yap M. Demographic and socioeconomic outcomes across the Indigenous Australian lifecourse: evidence from the 2006 Census. Canberra: Centre of Aboriginal Economic Policy Research, Australian National University, 2010. (Report no. 31.) http://caepr.anu.edu.au/Publications/research-monographs/2010RM31.php (accessed Nov 2011).

3 Strategic Review of Health Inequalities in England Post-2010 Commission. Fair society, healthy lives: the Marmot review. http://www.marmotreview.org/AssetLibrary/pdfs/Reports/FairSocietyHealthyLivesExecSummary.pdf (accessed Mar 2011).

4 Australian Government Department of Families, Housing, Community Services and Indigenous Affairs. Closing the Gap Prime Minister's report 2011. http://www.fahcsia.gov.au/sa/indigenous/pubs/closing_the_gap/2011_ctg_pm_report/Pages/ default.aspx (accessed Nov 2011)

5 Australian Government Department of Families, Housing, Community Services and Indigenous Affairs. Strategic Indigenous Housing and Infrastructure Program (SIHIP). 2011. http://www.fahcsia.gov.au/sa/indigenous/progserv/housing/Pages/ sihip.aspx (accessed Mar 2011).

6 Australian Government, Northern Territory Government. Delivering new, rebuilt and refurbished housing. Darwin: Northern Territory Government, 2011. http://www.territoryhousing.nt.gov.au/_data/assets/pdf_file/0008/85679/delivering.pdf (accessed Mar 2011).

7 MemmottP. Aboriginal housing: the state of the art (or the non-state of the art). Architecture Australia 1988; (June): 34-45.

8 Memmott P. Customary Aboriginal behaviour patterns and housing design. In: Memmott P, Chambers C, editors. TAKE2: Housing design in Indigenous Australia. Canberra: Royal Australian Institute of Architects, 2003:26-39.

9 Birdsall-Jones C, Corunna V, Turner N, et al. Indigenous homelessness. Melbourne: Australian Housing and Urban Research Institute Western Australia Research Centre, 2010. (Report no. 143.)

10 Bailie RS, McDonald EL, Stevens M, et al. Evaluation of an Australian Indigenous housing programme: community level impact on crowding, infrastructure function and hygiene. J Epidemiol Community Health 2011; 65: 432-437.

11 Black M. Learning what works: a 20 year retrospective view on international water and sanitation cooperation. Washington, DC: United Nations Environment Programme - World Bank Water and Sanitation Program, 1998.

12 Wigley JJ, Wigley B. Housing management training in rural Aboriginal communities. Canberra: AGPS, 1994

13 Northern Territory Government. Working Future: a Territory Government Initiative [website].http:// www.workingfuture.nt.gov.au (accessed Mar 2011).

14 Services and Indigenous Affairs. National Indigenous Housing Guide. Improving the living environment for safety, health and sustainability. http://www.fahcsia.gov.au/sa/indigenous/progserv/housing/Documents/default.htm (accessed Jun 2011).

$15 \mathrm{McDonald}$ E, Bailie R, Grace J, et al. An ecological approach to health promotion in remote Australian Aboriginal communities. Health Promot Int 2010; 25: 42-53.

16 Australian Government Department of Families, Housing, Community Services and Indigenous Affairs. Strategic Indigenous Housing and Infrastructure Program (SIHIP) - review of program performance - 2009. http://www.fahcsia.gov.au/sa/ indigenous/pubs/housing/sihip/Pages/default.aspx (accessed Mar 2011).

17 PricewaterhouseCoopers. Living in the sunburnt country - Indigenous housing: findings of the review of the Community Housing and Infrastructure Programme (CHIP) - 2007.http://www.fahcsia.gov.au/sa/indigenous/pubs/housing/ LivingSunburntCountry/Pages/default.aspx (accessed Mar 2011).

18 Northern Territory Government Department of Housing, Local Government and Regional Services. What are tenant's responsibilities? Q \& A. http://www.teritoryhousing.nt.gov.au/remotehousing/q_and_a (accessed Mar 2011).

19 Centrelink, Australian Government Department of Human Services. BasicsCard terms and conditions. http:// www.centrelink.gov.au/internet/internet.nsf/filestores/c0621_1001/\$file/c0621_100len.pdf (accessed Mar 2011).

20 Australian Government Department of Families, Housing, Community Services and Indigenous Affairs. Improving School Enrolment and Attendance through Welfare Reform Measure (SEAM). http://www.fahcsia.gov.au/sa/families/progserv/ welfarereform/pages/improvingschoolenrolmentattendance.aspx (accessed Mar 2011).

21 Northern Territory Government Department of Education and Training. Every Child Every Day. http://www.det.nt.gov.au/_ data/assets/pdf_file/0003/5168/EnsuringAttendanceParticipation.pdf (accessed Mar 2011).

22 Australian Government Department of Families, Housing, Community Services and Indigenous Affairs. Closing the Gap in the Northern Territory. Monitoring report. July to December 2010. Part two. http://www.fahcsia.gov.au/sa/indigenous/pubs/ nter_reports/closing_gap_NT_jul_dec_2010/Documents/part2/Part2_NTER_dec10.pdf (accessed Jun 2011).

23 Al-Yaman F, Higgins D. What works to overcome Indigenous disadvantage: key learnings and gaps in the evidence. Produced for the Closing the Gap Clearinghouse. Canberra: Australian Institute of Health and Welfare; Australian Institute of Family Studies, 2011. http://www.aihw.gov.au/closingthegap/documents/annual_papers/what_works_to_overcome_ disadvantage.pdf (accessed Jun 2011). 